Sanitary Inspector Roach for his kindness in visiting the house on several occasions to secure information and ticks for me.

\title{
A NEW SPECIES OF CHRYSOPA
}

\section{BY NATHAN BANKS}

New species of this genus are so uncommon in our country today that the finding of one of the most distinct forms hitherto known merits a separate article.

\section{Chrysopa eureka sp. nov.}

A heavy-bodied Chrysopa like robusta, but mostly dark and of quite different markings and venation.

Head pale yellowish, unspotted; palpi black; antennae black, basal joint pale. Thorax dark grey, heavily marked with black, underside and pleura mostly black. Pronotum with eight black spots arranged in two transverse rows, black spots on lateral lobes of the meso-and metanotum. Legs dull yellowish, a black band before tip of each femur, and the tarsi somewhat darkened. Wings with mostly black cross-veins, gradates, and apical forks, the longitudinal veins with streaks of black; stigma greyish, with several cross-veins behind margined with dark.

Face broad; antennae rather short and stout; pronotum very broad, but little narrowed in front; rest of thorax very broad; abdomen stout and short; legs stout, much more so than in the common species, the front and mid tarsi more than one-half the length of the tibiae.

Wings moderately broad; venation not dense, about 17 costals, eight connecting veins from the radial sector to radius, seven cubital cross-veins beyond third cell, divisory veinlet ends much beyond the cross-vein, divisory cell of moderate size, about five gradates in each series, the two rows not very near together and the outer one hardly nearer to the margin than to the other row. Length fore-wing $17 \mathrm{~mm}$, breadth $5.5 \mathrm{~mm}$.

From Hope, Ark., 22 Aug. (L. Knobel), at light. Holotype in Museum of Comparative Zoology. 

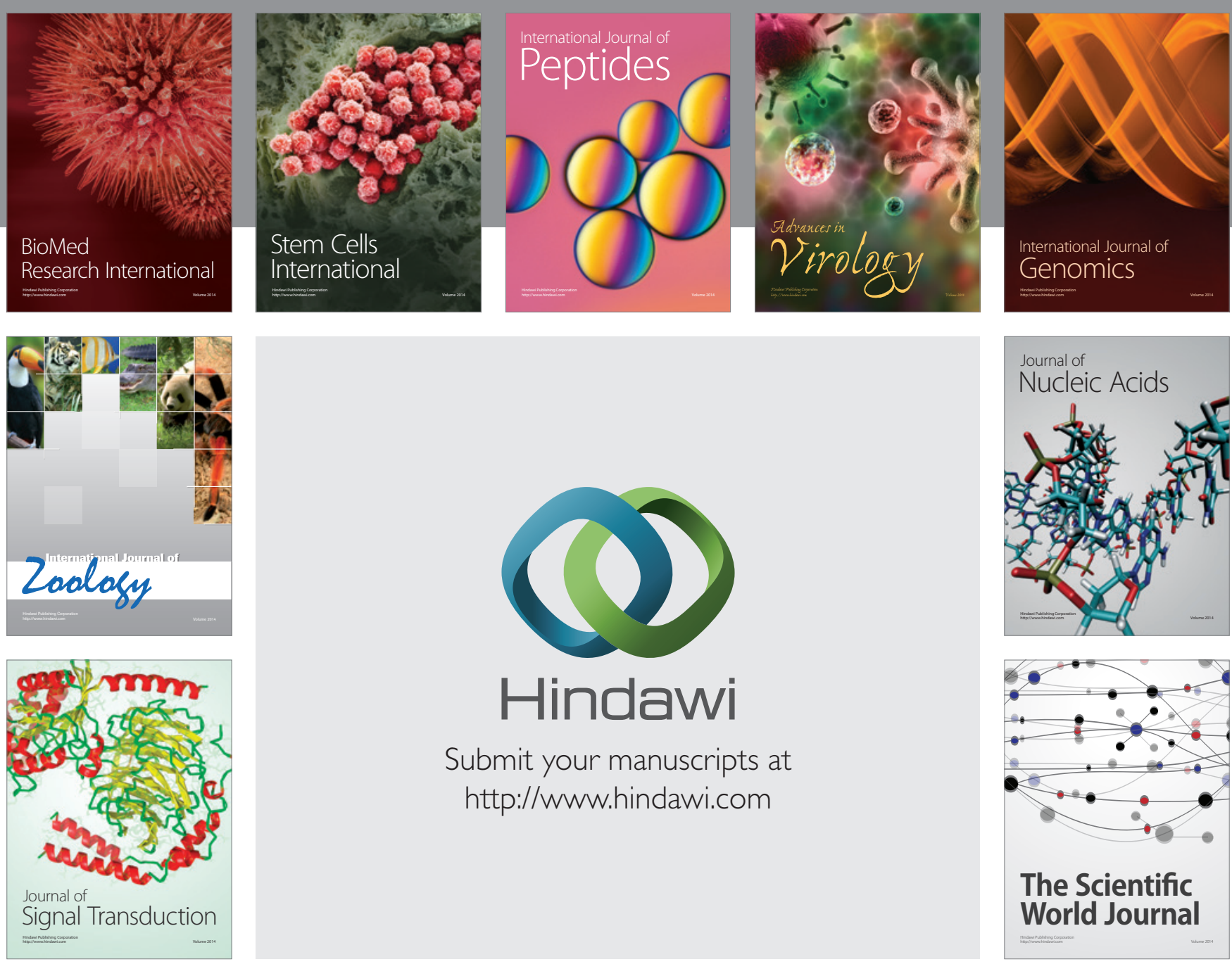

Submit your manuscripts at

http://www.hindawi.com
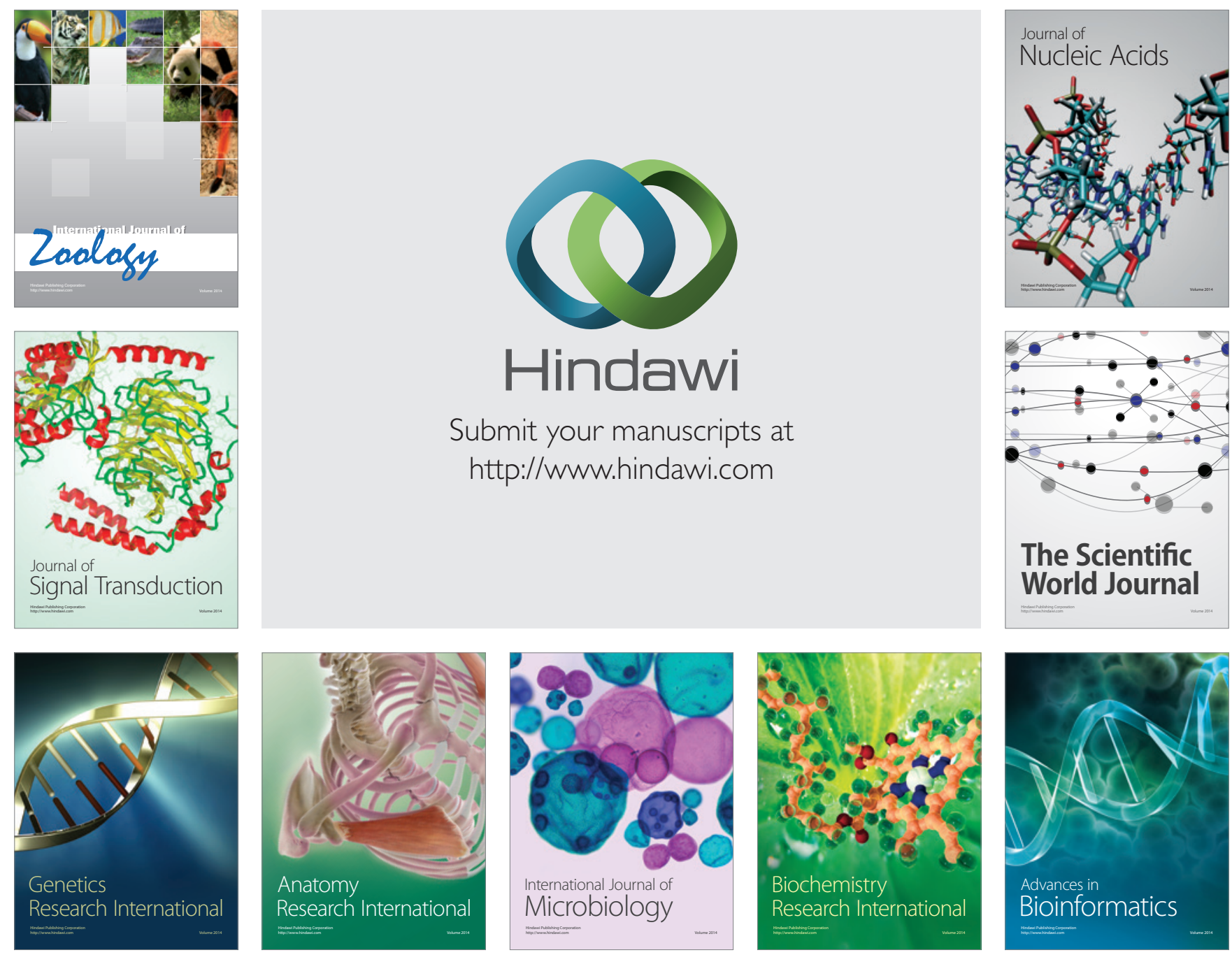

The Scientific World Journal
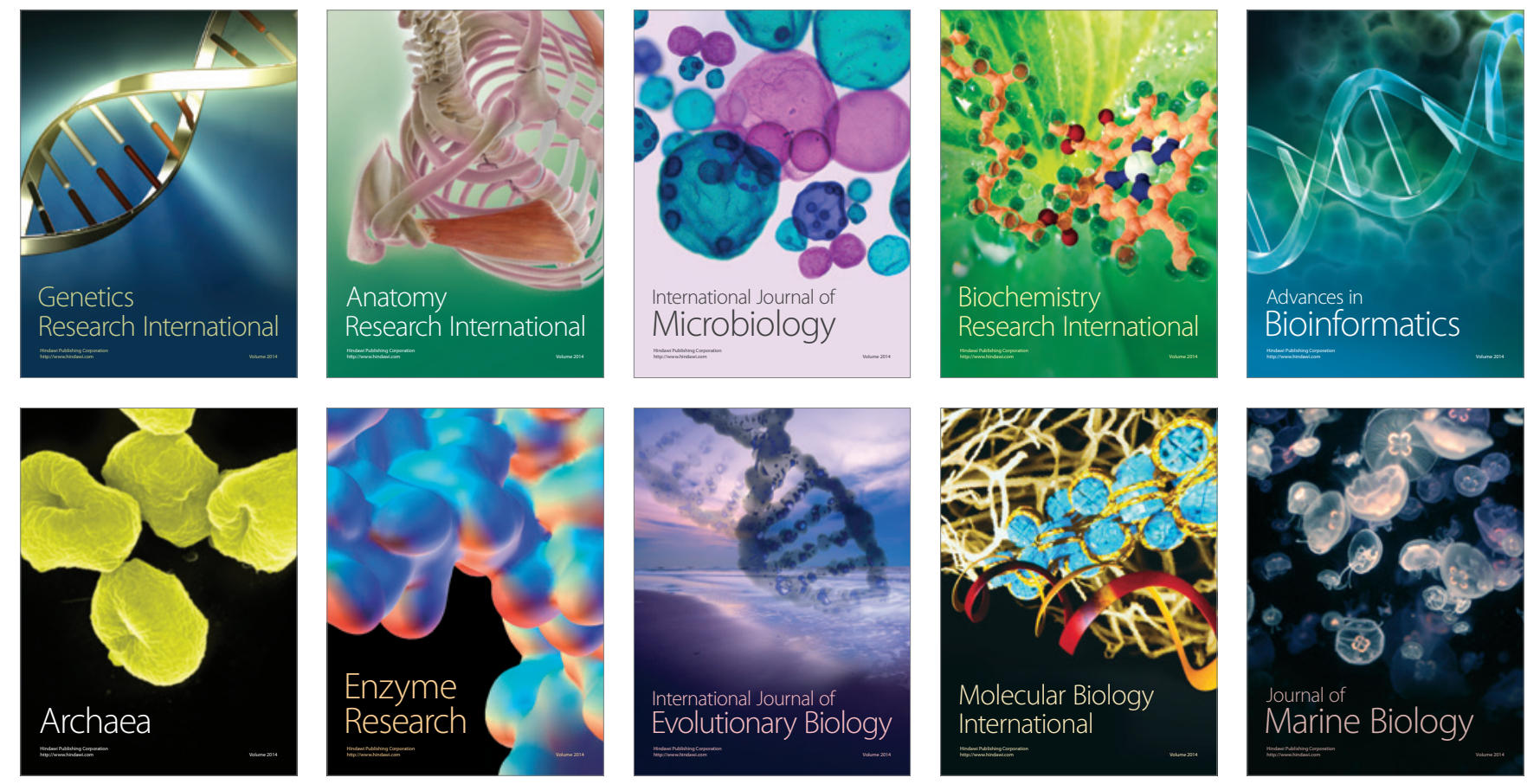